\title{
Reconstruction of the National Legal System: Study the Implementation of the Maqâsid al-Shari'ah Theory
}

\author{
Achmad Faidi
}

\begin{abstract}
Reconstruction of the National Legal System: Study the Implementation of the Maqâsid al-Shari'ah Theory. This paper discusses the implementation of the theory of maqâsid al-shariah in the formation of a national legal system in Indonesia. Colonialism in the past has made national law covered with the nuance of European Continental legal system which is not compatible with the character of the national culture. The awareness to reconstruct the national legal system has echoed since the 1998 reform, but until now it has not found the right construction formula. This article offers the theory of maqâsid al-shari'ah as one of the tools in an effort to reconstruct the national legal system. Based on author analysis, the concept of maqâsid al-shari ah is suitable to be applied because it adopts the noble values contained in the national ideology of Pancasila as well as the legal principles that exist in Islam as a religion of the majority of the population of this country.
\end{abstract}

Keywords: reconstruction, legal system, maqâsid al-shari'ah

\begin{abstract}
Abstrak: Rekonstruksi Sistem Hukum Nasional: Studi Implementasi Teori Maqâsid al-Syarî́ah. Tulisan ini membahas tentang implementasi teori maqâsid al-syarî́ah dalam pembentukan sistem hukum nasional di Indonesia. Kolonialisme di masa lalu telah menjadikan hukum nasional kental dengan nuasa sistem hukum Eropa Continental. yang tidak sesuai dengan karakter budaya bangsa. Kesadaran untuk merekonstruksi sistem hukum nasional telah bergema sejak reformasi 1998, namun hingga kini belum menemukan formula konstruksi yang tepat. Artikel ini menawarkan teori maqâsid alsyarîa $a h$ sebagai salah satu piranti dalam upaya merekonstruksi sistem hukum nasional. Berdasarkan analisis penulis, konsep maqâsid al-syarî́ah cocok untuk diterapkan karena ia mengadopsi nilai-nilai luhur yang terdapat dalam ideologi nasional Pancasila sekaligus prinsip-prinsip hukum yang ada dalam agama Islam yang merupakan agama mayoritas penduduk negeri ini.
\end{abstract}

Kata Kunci: rekonstuksi, sistem hukum, maqâsid al-syarî‘ah 


\section{Introduction}

In the context of legal state, ${ }^{1}$ every independent and sovereign country should have a national legal system as a reflection of the character and personality of the nation. France, for instance, has the Civil Code ${ }^{2}$ and proud of it. Indonesia, in contrast, still does not have a national legal system that truly reflects the character and personality of the Indonesian nation. ${ }^{3}$

The legal formula applied in the criminal and civilian fields in Indonesia ${ }^{4}$ is still a legacy system of Dutch colonial law. ${ }^{5}$ It can be said that the Indonesian people have not had a legal system or formula originating from their own traditions, as it still uses the laws and regulations inherited by the Dutch colonial government. Only on the basis of political considerations and nationalism that the laws and regulations are changed their names, such as Kitab Undang-undang Hukum Pidana (KUHP/Criminal Code) is a nationalization of Wetboek van Strafrechts; Kitab Undang-undang Hukum Perdata (KUH Perdata/

${ }^{1}$ Moh. Mahfud M. D and Tirto Suwondo, Hukum dan Pilar-pilar Demokrasi (Yogyakarta: Gama Media, 1999), p. 9. Cees Fasseur, 'Cornerstone and Stumbling Block: Racial Classification and the Late Colonial State in Indonesia', The Late Colonial State in Indonesia: Political and Economic Foundations of the Netherlands Indies, 1942 (1880), p. 31-56. Jaap Timmer, 'Being Seen like the State: Emulations of Legal Culture in Customary Labor and Land Tenure Arrangements in East Kalimantan, Indonesia', American Ethnologist, 37, no. 4, (2010), p. 703-12 <https://doi. org/10.1111/j.1548-1425.2010.01279.x>.

2 Asis Safioedin, Beberapa Hal Tentang Burgerlijk Wetboek (Alumni, XVI, 1973), p. 79. Cees Fasseur, 'Colonial Dilemma: Van Vollenhoven and the Struggle between Adat Law and Western Law in Indonesia', in The Revival of Tradition in Indonesian Politics (Routledge, 2007), p. 70-87. Daniel S. Lev, 'Colonial Law and the Genesis of the Indonesian State', in Law and Society in East Asia (Routledge, 2017), p. 3-20. M. A. Jaspan, 'In Quest of New Law: The Perplexity of Legal Syncretism in Indonesia*', Comparative Studies in Society and History, 7, no. 3, (1965), p. 252-66 <https://doi.org/10.1017/S0010417500003674>.

${ }^{3}$ C. S. T. Kansil, Pengantar Ilmu Hukum dan Tata Hukum Indonesia (Balai Pustaka, 1992), p. 200-201.

${ }^{4}$ Making Islamic criminal law as a basis for renewal to replace criminal law originating from dutch colonialism, taking into account juridical, philosophical and sociological aspects, so that Islamic criminal law has relevance to Indonesian society. Jimly Asshiddiqie, Pembaharuan Hukum Pidana di Indonesia' (Bandung: Angkasa, 1996), p. 158-242.

${ }^{5}$ Lauren Benton, 'Colonial Law and Cultural Difference: Jurisdictional Politics and the Formation of the Colonial State', Comparative Studies in Society and History, 41, no. 3 (1999), p. 563-588. G. Galudra and M. Sirait, 'A Discourse on Dutch Colonial Forest Policy and Science in Indonesia at the Beginning of the 20th Century', 2009, p. 524-533<https://doi. org/info:doi/10.1505/ifor.11.4.524>. 
Civil Code) from Burgerlijk Wetboek; Kitab Undang-undang Hukum Dagang (KUH Dagang/The Commercial Law Act) from Wetboek van Koophandel. ${ }^{6}$

The colonial legal system that has been implemented is not necessarily suitable with the character of colonies. The structure and culture of the colonial (colonial government) differ from the structure and culture of the colonies. Although more than three centuries Indonesia was colonized by the Dutch, it does not mean that the Dutch legal system (European Continental) is suitable to be applied and preserved in Indonesia. ${ }^{7}$ The choice of the right legal system for a nation can guarantee the effectiveness and usefulness of the law whereas the choice of wrong legal system may become an obstacle to the purpose of the law created.

Vollenhoven criticized that "... how is it possible in a country inhabited by millions of people who have their own traditions, moreover the Muslim population who is very obedient to the law of its own writing, can be treated by a law intended only to regulate the lives of Europeans. It may be feared that policies like this will destabilize the joints of the lives of indigenous people..."

To be sure, the Dutch legal tradition along with its system is not the right law to be preserved in Indonesia. Although it has not been explicitly acknowledged - both in the constitution and in the form of other legal products - that Indonesia adheres to one of the particular legal systems, a reconstruction of the national legal system is really urgent to be carried out immediately in order to save the spirit of national law which, up to now, tends to be neglected by some community groups in Indonesia. ${ }^{9}$

\footnotetext{
${ }^{6}$ Imam Syaukani, Rekonstruksi Epistemologi Hukum Islam Indonesia dan Relevansinya Bagi Pembangunan Hukum Nasional (Jakarta: RajaGrafindo Persada, 2006), p. 241.

${ }^{7}$ Lev, Pierre Legrand, 'European Legal Systems Are Not Converging', International \& Comparative Law Quarterly, 45, no. 1, (1996), p. 52-81. <https://doi.org/10.1017/ S0020589300058656>. Ugo Mattei, 'Three Patterns of Law: Taxonomy and Change in the World's Legal Systems', The American Journal of Comparative Law, 45, no. 1, (1997), p. 5-44 $<$ https://doi.org/10.2307/840958>.

${ }^{8}$ Lev, Pierre Legrand, 'European Legal Systems Are Not Converging'.

${ }^{9}$ The emergence of the right Islamic movements and several regions demanding the
} 
By improving the national legal system, the author believes that it can change people's perceptions of the existence and status of national law (positive law) so that the existing law in Indonesia is no longer underestimated or becoming merely supplementary law. ${ }^{10}$ This paper discusses the reconstruction effort of the national legal system to realize a more authoritative and efficient national law by using the theory of maqâsid al-shariah, as a theory commonly used in the process of excavation (istinbâth) and the development of Islamic law.

\section{Dialectics of the National Legal System}

As it was mentioned earlier, there is no written acknowledgmentboth in the constitution and other legal products - that Indonesia adheres to a particular world legal system either Continental Europe, Anglo Saxon, or Islamic legal systems. But in its dialectics, these three legal systems always appear in the legal development of Indonesia, particularly, the continental European legal system. ${ }^{11}$

History records several legal systems that have been developed in Indonesia; namely Continental Europe legal system, Anglo Saxon legal system, customary law system, and the Islamic legal system.

The Continental Europe law system is a legal system that has a basis or a reference to applicable law prioritizing the source of written rule of law. This legal system is developed in mainland European countries which are often referred to as "civil law". Among principles adopted in this legal system is "legal certainty". Legal certainty can only be realized if human legal actions are regulated by written regulations such as KUHP, KUHAP, KUH Perdata, KUH Dagang, etc.

adoption of Islamic Shari'a has become evidence that they reject the legal system applied in Indonesia. The shadow of the colonial law products in the criminal and civil law system in Indonesia makes some groups do not believe in the substance of justice that can be achieved, considering the law system tends to be secularistic which is very different from the Indonesian ideology (Pancasila) system which is very religious.

${ }^{10}$ Mary Ann Glendon, The Transformation of Family Law: State, Law, and Family in the United States and Western Europe (University of Chicago Press, 1996).

${ }^{11}$ Munir Fuady, Teori-Teori dalam Sosiologi Hukum (Kencana, 2015), p. 32. 
Similarly, the Anglo Saxon legal system is a legal system based on jurisprudence, namely the decisions of previous judges which later became the basis of the decisions of subsequent judges. In Indonesia, jurisprudence is also recognized as one of the sources of law. The Anglo Saxon legal system tends to prioritize customary law that runs dynamically in line with the dynamics of society. ${ }^{12}$ The establishment of law through judicial institutions with a system of jurisprudence is considered better so that the law is always in line with the sense of justice and the community benefit in real terms.

In Anglo Saxon legal system, ${ }^{13}$ the role given to a judge is very broad. The judge functions not only as the party tasked with setting and interpreting legal regulations but also play a major role in shaping the whole system of people's lives. In addition, it can create new laws that become a guideline for other judges to settle similar cases. In the event that there is no other judge's decision from the case or the previous judge's decision, the judge may determine the decision based on his own values of justice, truth, and common sense.

Next, the customary law system (adat-recht). ${ }^{14}$ The Customary law is a law that lives and develops in a society for a long time based on the values of the community, either original or syncretic. ${ }^{15}$ In Indonesia,

${ }^{12}$ Peter De Cruz, Comparative Law in a Changing World (Cavendish Pub., 1999), p. 37.

${ }^{13}$ Stephen S. Chandler, 'The Role of the Trial Judge in the Anglo-American Legal System', American Bar Association Journal, 50 (1964), 125.

${ }^{14}$ Franz Von Benda-Beckmann and Keebet Von Benda-Beckmann, 'Myths And Stereotypes About Adat Law: A Reassessment of Van Vollenhoven in the Light of Current Struggles over Adat Law in Indonesia', Bijdragen Tot de Taal-, Land-En Volkenkunde, 167, no. 2/3 (2011), p. 167-95. Tsuyoshi Kato, 'Different Fields, Similar Locusts: Adat Communities and the Village Law of 1979 in Indonesia', Indonesia, 1989, p. 89-114. <https://doi.org/10.2307/3351077>. Kallie Szczepanski, 'Land Policy and Adat Law in Indonesia’s Forests', Pacific Rim Law \& Policy Journal, 11 (2002), p. 231. Raden Supomo, 'The Future of Adat Law in the Reconstruction of Indonesia', Southeast Asia in the Coming World, 1953, p. 217-35. Ratno Lukito, 'Law and Politics in Post Independence Indonesia: A Case Study of Religious and Adat Courts', Studia Islamika, 6, no. 2 (1999).

15 The application of customary law in Indonesia is very diverse, each region has its own customary law and is different from one another. Ranging from those that are clearly very close to Islamic law to those who still adhere to animism, there are customary laws that are patrilineal, matrilineal but also those that follow a bilateral system. Van Vollenhoven divides 19 customary law circles in Indonesia, namely Aceh, Gayo, Minangkabau, South Sumatra, Malay, Bangka-Belitung, Kalimantan, Minahasa, Gorontalo, Toraja, South Sulawesi, 
this system was first introduced by Christian Snouck Hurgronye in 1893 as a term for Indonesian codified people's law. Generally, customary law is not written. It lives in the habits of the people, develops in the words of the Indonesian people according to accent, intuition and local language.

The last system is the Islamic legal system. Islamic legal system becomes a source of law in Indonesia due to the population of Indonesia, which is predominantly Muslim. The system appears and influences the rules that apply in Indonesia, as a manifestation of the needs of the Muslim community. They are the marriage law (UU/1/ 1974), the law on religious justice (UU/7/1989), the law on the implementation of the pilgrimage (UU/17/1999), as well as the Zakat Law (UU/36/1999). The existence of these acts and regulations proves to strengthen the existence of Islamic law in Indonesia.

Among the four legal systems mentioned earlier, the most dominant influence is the continental Europe legal system with its Wetboek van Strafrechts, Burgerlijk Wetboek, Wetboek van Koophandel products. These legal books until now remain the main reference for criminal cases as well as civil and trade disputes in Indonesia. In spite of their foreign characters distinctive to the character and beliefs of the Indonesian people, no legal body dares to reconstruct them totally except in part let alone to create new laws.

From the dialectical record of the legal system, it illustrates that Indonesia still does not have a legal system that truly fits the personality of the nation. The national legal construction (positive law) that applies in Indonesia seems still not rooted in the culture of Indonesian society. There is still a dichotomy in community understanding between religious law (Islamic law) and state law (positive law). People percepts that positive law can only be obeyed as long as it does not contradict to religious law. In addition, positive law that applies in Indonesia is seen as a product of western law that tends to be secularistic and far from the

Ternate, Maluku, Irian, Timor, Bali and Lombok, Central Java and East Java Solo-Yogyakarta and West Java. 
character of people in the archipelago. Consequently, It is not uncommon there emerge some groups of people who disobey or even reject the establishment of the rule of law in this country. In fact, religious law (Islamic law) and the state law (positive law) have similar goal, namely to realize order and harmonious life of the nation in order to achieve peaceful and prosperous country.

\section{Islamic Law and the Theory of Maqâsid al-Sharîah}

God has a purpose in making a rule. In the literature of Islamic law, the purpose of the law is known as the maqâsid al-sharîah. Through the Qur'an-the book that descends to the Prophet Muhammad,Allah explains the intention and purpose of the shari'ah, that is, for the sake of the realization of salvation and the benefit of humanity, both in the world and in the hereafter. ${ }^{16}$ The Qur'an has asserted itself as a book of guidance and mercy for human ${ }^{17}$ beings. It also states that the Prophet Muhammad was sent to the world to establish mercy to the universe (rahmatan lil'alamin), aiming at perfecting human ethics on this earth. ${ }^{18}$

The substantive purpose of the universalism of Islamic law (maqâsid al-sharîah), according to Ash-Syatibi, is the intrinsic goal of shariah (Islamic law) which has been recognized by all scholars without denial. 19 From research on sacred texts both the Qur'an and al-Hadith, Ibn Qayyim al-Jauziyah argued that the shari'ah (Islamic law) was built for the benefit of humans and other universal humanitarian purposes, namely benefit justice, blessing, and wisdom. ${ }^{20}$ These principles serve as the basis and substance of every design or formulation of Islamic jurisprudence.

${ }^{16}$ Q.s. al-Baqarah [2]: 37.

${ }^{17}$ Q.s., al-Baqarah [2]: 2. Q.s. al-Qashas [28]: 86.

${ }^{18}$ Q.s. al-Ahzab [33]: 21. Q.s. al-Anbiya [21]: 107.

${ }^{19}$ Shabnam Ishaque, 'Islamic Principles On Adoption: Examining The Impact of Illegitimacy and Inheritance Related Concerns In Context of A Child'S Right To An Identity', International Journal of Law, Policy and the Family, 22, no. 3 (2008), p. 393-420. <https://doi.org/10.1093/ lawfam/ebn009>.

${ }^{20}$ Ibn al-Qayyim al-Jawziyyah and Abi Bakr Ayyub, Ilâm al-Muwaqqiî̀n 'an Rabb al'Alamîn' (Bayrut, Dâr al-Kutub al-'Ilmiyah, 1991), p. 3. 
The maqâsid theory is always in the minds of Islamic jurists (fuqaha) particularly in carrying out the process of construction and reconstruction (istinbât) of Islamic law. Avoiding the theory of maqâsid al-shariah means deviating the ideals of Islamic law. ${ }^{21}$

The view of applying maqâsid al-sharîah was also shared by prominent Islamic thinkers, such as Al-Ghazali (d. 505 AH / 1111 AD), ${ }^{22}$ Fakhr al-Din al-Razi (d. 606 H.), ${ }^{23} \mathrm{Izz}$ al-din Ibn 'Abd al-Salam (660 H.), ${ }^{24}$ Shihab al-Din al-Qarafi (d. 685 H.), ${ }^{25}$ Najm al-Din alTufi (d. 790 H.), ${ }^{26}$ Abu Ishaq al-Syatibi (d. 790 H.), ${ }^{27}$ Muhammad bin al-Thahir bin 'Asyur (d. 1393 H.1973 AD), ${ }^{28}$ 'Allal al-Fasi (d. 1393 H. / 1973 AD), and others. They agree that shari'ah (Islamic law) has no other purpose except to realize the good of human beings, (jalb al-masâlih), and reject the form of damage (dar al-mafâsid). ${ }^{29}$ An expression that shari'a (Islamic law) was built for the sake of happiness (sa'adah), both in the world and in the end (ma'âsy wa ma'âd) fully reflects the benefit of Islamic law itself.

${ }^{21}$ Nurcholish Majid, Islam: Doktrin dan Peradaban: Sebuah Telaah Kritis Tentang Masalah Keimanan, Kemanusiaan, dan Kemodernan (Jakarta: Yayasan Wakaf Paramadina, 2000), p. 466.

${ }^{22}$ Muhammad Sulayman Ghazzali, 'al-Mustasfa Min Ilm al-Usul' (Ttp.: Tnp., 1997), p. 26.

${ }^{23}$ Fajr al-Din al-Razi, al-Mahsûl fì Ilm Usûl al-Fiqh (Ttp.: Dâr al-Kutub al-Ilmiyya, 1988), p. 45.

${ }^{24}$ Izzuddin bin'Abd al-Salam, 'Qawâiid al-Ahkâm Fi Masâlih al-Anam' (Bayrût: Libanon Muassasat al-Rayyan, 1998), p. 76.

${ }^{25}$ Shihab al-Din al-Qarafi, 'Sharh Tanqîh al-Fusûl Fi Ikhtisâr al-Mahsûl Fi al-Usûl, Ed', Taha'Abd al-Ra'uf Sa'd (Cairo: Maktabat al-Kulliyyat al-Azhariyya, 1973), p. 15.

${ }^{26}$ This Islamic legal scientist from the Hanbali school adheres to a school that prioritizes the general benefit of nas and ijma. He stated that in the event of a collision between universal benefit and nas or ijma, then what must be won is the public interest. For al-Tufi, in lafziyah, indeed sometimes invites dissent, while maintaining benefit (riyâa al al-masalih) is something that has been agreed upon by all. Then choosing maslahah is more primary (awla). Mustafa Zaid, 'al-Maslahah Fi al-Tasyrî' al-Islâmi Wa Najmuddin al-Tûfi', (Bayrût: Dâr al-Fikr, 1954), p. 227. This opinion received strong responses from other scholars, such as Sa'id Ramdlan al-Buthi. Sa'id said that the reasons stated by al-Tûfi were not strong enough, because they were rejected Muhammad Sa'îd Ramadhân al-Bûthî, Dhawâbith al-Mashlahah Fî̀ al-Syarî̀ah al-Islamiyyah (Bayrût: Dâr al-Muttahidah, 1992).

${ }^{27}$ Abû Ishaq al-Syatibi, 'al-Muwafaqat Fi Usûl al-Syariả (Vol. 1)', (Kairo: Dâr Kutub al-'Ilmiyah, 2003).

${ }^{28}$ Yusuf Hamid Alim, 'al-Maqasid al-'Ammah Lil-Shariah al-Islamiyah' (Herndon, VA: International Institute of Islamic Thought, 1991).

${ }_{29}$ Abd Moqsith Ghazali, Moqsith, Reorientasi Istinbath NU dan Operasionalisasi Ijtihad Jamai, dalam Kritik Nalar Fiqih NU (Jakarta: Lakpesdam, 2002). 
One method developed by the classical scholars (tabi'in) in understanding the problem not regulated in the texts (Qur'an and alHadith) is by doing ijtihâd. ${ }^{30}$ They tried to direct their sincerity with optimal efforts in trying to explore shari'ah in order to reach maslahah as the main goal (maqâsid al-sharîah) of development. ${ }^{31}$ Maslahah is another name for maqâsid as the stipulation of law in Islam must lead to the goodness (maslabah). ${ }^{32}$ The essence of maqâshid al-sharîah theory is to create goodness while avoiding evil, or attracting benefits and rejecting of badness (madharat).

Based on the theory of maqâshid al-sharîah, Hasbi As-Siddiqi identifies three characters of Islamic Law that never change, namely: takâmul, wasathiyyah, and harakah. Takâmul means perfect and complete in the sense that Islam unifies Muslims despite their differences in ethnicity and tradition. Wasathiyyah means harmony, moderate, in the sense that Islamic law takes a middle course, a balanced way, that harmonizes facts with legal ideas and not too emphasizes on the importance of material aspect but also spiritual. Harakah i.e dynamic means Islamic law has the ability to move and develop in accordance with development and progress. $^{33}$

These three characteristics make Islamic law able to adapt to any kind of law, including the national legal order in Indonesia. The flexibility of Islamic law with the theory of maqâshid al-sharîah not only answers the existing problems but also fills in the legal vacuum that is still not regulated textually.

So, in the effort to reconstruct the national legal system, it justifiable to borrow the theory of maqâsid al-sharîah as a systematic knife of analysis or methodology to produce a national legal system

${ }^{30}$ A. Qodri Azizy and M. Zain, Reformasi Bermazhab: Sebuah Ikhtiar Menuju Ijtihad Sesuai Santifik-Modern (Teraju, 2003), p. 27.

${ }^{31}$ Abû Ishaq al-Syatibi, 'al-Muwafaqat Fi Usûl al-Syari'ah, p. 89.

${ }^{32}$ Mohammad Hashim Kamali, “Maqâsid al-Sharîah": The Objectives of Islamic Law', Islamic Studies, 38, no. 2 (1999), p. 193-208.

${ }^{33}$ Masnun Tahir, 'Pemikiran T. M. Hasbi Ash-Shiddieqy: Sumber Hukum Islam dan Relevansinya dengan Pemikiran Hukum Islam di Indonesia', Al-Ahwal: Jurnal Hukum Keluarga Islam, 1, no. 1 (2016), p. 117-52. 
firmly rooted in society along with its compliance and submission.

Furthermore, if we look at the discourse notes that took place among the founding fathers at the time of the constitutional formation (the 1945 Constitution), it become clear that they were very careful in formulating an article of the constitution to reach the maslahat for all Indonesian people that was mutual prosperity and welfare to all people of Indonesia. Although the formulation in the Jakarta charter was considered ideal by some Muslim groups, as the editorial has the potential to divide plural Indonesian society, the formulation of the Jakarta Charter was deleted from the preamble of the constitution.

\section{Reconstruction of the Legal System and Theory of Maqâsid al- Shari'ah}

In principle, every construction of a legal system built on the characteristics of the community will not be rejected. The law exists because of the existence of society, and the law was created for good (benefit) for the community. ${ }^{34}$ Of course, in this case, all forms of goodness (maslahah) desired by society. If the law with all its systems is not able to bring goodness (maslahah) dreamed of by its people, surely the law will be abandoned or even will be rejected.

The cultural condition of the people in Indonesia requires the right perspective in formulating legal rules or determining the legal system. Incorrect in determining the paradigm may result in the dysfunction of the law. Forcing the character of continental European law to be preserved in Indonesia will certainly face resistance from society so that public perceptions of national law or state law (positive law) tend to be negligent. The positive law is seen as lower than religious law. In Artidjo Alkostar's view, Wetboek van Strafrechts is not compatible with a cultural characteristic of Indonesia. This can be seen that the Criminal Code (KUHP), which is a nationalization of Wetboek van Strafrechts, seems to be gender biased, unfair and persecuting women. The Code which

${ }^{34}$ Satjipto Rahardjo, Sosiologi Hukum Esai Esai Terpilih (Yogyakarta: Genta Publishing, 2010), p. 18. 
basically originated from French Code Penal, and later compiled in 1881 and implemented in 1886, was very discriminative, putting women in a weak position. Indeed, the character and morals of the Criminal Code which underestimate the degree of women was a reflection of the social system that prevailed at the time when the Criminal Code was formed in Europe. ${ }^{35}$

Similarly, the Western legal system has a different view of morality and law. In Western societies, the law and morality have no relationship at all. They reasoned that the issue of decency was a private matter, so there was no authority from legal institutions to regulate it as long as no harm against other parties. This can be seen in several provisions decency delicts both in Civil Law and Common Law, are regarded as private matters, even in some countries, these acts are not considered as acts that can be punished, as long as there is no element of coercion or involvement of minors, weak or powerless person and not carried out in the public sphere. The western legal system is only entitled to regulate general affairs, such as theft, persecution, murder and so on. Of course, this culture is very much different from the culture of Indonesian society, which makes the religious value as the main guidance in every activity of life. ${ }^{36}$

In the Islamic legal system, moral and law always go hand in hand, not only the material law that be applied, but also the moral elements contained in it. Thus, questioning the extent to which the relationship between law and morals in Islamic law is actually less relevant because, in the format of Islamic law, law, religion, and morality are inseparable entities. Shari'a came with the aim of maintaining moral values and the Prophet Muhammad himself was sent to rectify morals. ${ }^{37}$

${ }^{35}$ Artidjo Alkostar, "Pembangunan Hukum Nasional: Studi Introspektif Terhadap Rumusan Delik yang Tidak Beresensi Keadilan”, In Artidjo Alkostar and M. Sholeh Amin (ed.), Pembangunan Hukum dalam Perspektif Politik Hukum Nasional (Jakarta: Rajawali Pers, 1986), p. 207-208.

${ }^{36}$ Imam Gunawan, 'Perspectives of Pancasila: Leadership Education's Values and Ethics', 2nd ICET Theme: "Improving the Quality of Education and Training Through Strengthening Networking", 2016, p. 417.

${ }^{37}$ Duski Ibrahim, Metode Penetapan Hukum Islam: Membongkar Konsep al-Istiqra' alMánawi asy-Syatibi (Yogyakarta: Ar-Ruzz Media, 2008), p. 208. Kutbuddin Aibak, Metodologi Pembaharuan Hukum Islam (Yogyakarta: Pustaka Pelajar, 2008), p. 60-65. 
In the theory of maqâshid al-sharîah, there are provisions intended to maintain and protect moral values. These can be found in the study of ushîl fiqh which establishes the principles of maqâshid al-sharìah known as al-dharûriyat al-khamsah (protection of the five basic elements of human interest). These elements include hifzh al-din (protection of religion/belief), hifzh al-nafs (protection of the soul), hifzh al-nasl wal al-irdh (protection of genetics and honor), hifzh al-'aql (protection of reason) and hifzh al-mâl (property protection). These five principles are not much different from the five precepts in Pancasila which were formulated by the founders of the nation to provide grounding signs in the life of the nation and state.

Protection of honor (hifzh al-irdh) ${ }^{38}$ as one of the main objectives of Islamic law proves that law and morals cannot be separated in Islam. The prohibition of adultery with the threat of severe punishment is an example of the rule in Islamic law to enforce moral values. In Islamic law, adultery is a vicious crime undermining moral values, either carried out by married or unmarried couples.

Rebuilding the national legal system ${ }^{39}$ in accordance with the personal character and culture of Indonesia is more justifiable than taking another legal system. If not, the public perception of positive law in Indonesia will still not change, that state law is number two law. Such perceptions lead to weak compliance and submission of society to state law (positive law).

In the effort to further strengthen the existence of positive law in Indonesia, one thing to do is to remove the dichotomy in people's understanding of the relationship between religion and state law. This dichotomous perception of the community may inhibit every effort to build law enforcement because the people disregard it.

${ }^{38}$ Ulfa Masamah and Mualimul Huda, 'Multicultural Education and the Nationalistic Reality (Photograph the Role of Teachers In Building A Multicultural Awareness In Indonesia)', QIJIS (Qudus International Journal of Islamic Studies), 4, no. 1 (2016), p. 68-81. <https://doi. org/10.21043/qijis.v4i1.1578>.

${ }^{39}$ Busthanul Arifin, 'Supremasi Hukum di Indonesia', in A. Qodri Azizy, et. al., Membangun Integritas Bangsa (Jakarta: Renaisan, 2004). 
According to Lawrence M. Friedman, there are at least three elements formed in each legal system; They are the substantive element, (a legal substance), structural elements (legal structure) and cultural elements (legal culture). ${ }^{40}$

The first element—-the legal substance or legal material-comprises of written or unwritten regulations that must be developed based on the national values. The legal content that is not in accordance with the cultural values of the nation will be easily mocked or ignored. Creating a new legal formula in the context of criminal and civil cases in Indonesia is necessary to move away from Wetboek van Strafrechts and Burgerlijk Wetboek which are products of Dutch law.

The second element-legal structure-is an institutional system and mechanism that supports the establishment and implementation of the law in Indonesia. Included in the legal-institutional structure, among others, are the judicial institutions, law enforcement apparatus, legal enforcement mechanisms, and the law enforcement oversight system. Again in this element, the model of a legal structure must meet the cultural character of the society. Any institutional structure that does not reflect a social environment of the community, will face with difficulties in implementation.

The third element-legal culture-represents human attitudes towards beliefs, values, thoughts, expectations, and the legal system, ${ }^{41}$ Legal culture is an atmosphere of social thought and social power that determines how a law is used, avoided, or misused. Legal culture is closely related to community legal awareness. The higher legal awareness of the community the higher the possibility of creating a good legal culture and changing people's perceptions of the law. In simple terms, the level of public compliance with the law is an indicator of functioning the law. Such things are usually created from the public's impression of the substance and legal structure.. The more impressive the presence of the substance and legal structure in the midst of society, the higher the

${ }^{40}$ Lawrence M. Friedman, 'Sistem Hukum Perspektif Ilmu Sosial' (Bandung: Nusa Media, 2009), p. 8.

${ }^{41}$ Lawrence M. Friedman, 'Sistem Hukum Perspektif Ilmu Sosial', p. 8. 
appreciation and perception of the community towards the supremacy of law. In other words, the level of legal awareness of the community always depends on synergy with the acceptance of society towards the substance and legal structure that develops.

The relationship among the above- three elements is related to one another. All three must be touched in an effort to obtain the more dignified and authoritative national legal products. The obedient and the compliance of society to national law is not because they were forced or suppressed, in contrast, it arises from their awareness to create a better, fair and prosperous society.

\section{Conclusion}

Every law-whatever its form-has the same purpose (maqasid) namely realizing goodness for society. A good national law can be reached if it is rooted in the tradition, ideology, culture and fundamental character of the people. With regard to the legal system in Indonesia, the system should adopt national ideology Pancasila which combines religious values and legal morality together. This can be done by implementing the theory of maqasid al-shari'ah, an approach based on Islamic law that is relevant to the cultural and philosophical values of Indonesia ideology.

\section{Bibliography}

Aibak, Kutbuddin. Metodologi Pembaharuan Hukum Islam. Yogyakarta: Pustaka Pelajar, 2008.

Alim, Yusuf Hamid. 'al-Maqâsid al-'Ammah Lil-Shari'ah al-Islamiyah'. Herndon, VA: International Institute of Islamic Thought, 1991. Arifin, Busthanul. 'Supremasi Hukum di Indonesia', In A. Qodri Azizy, et. al., Membangun Integritas Bangsa. Jakarta: Renaisan, 2004.

Azizy, A. Qodri, and M. Zain. Reformasi Mermazhab: Sebuah Ikhtiar Menuju Ijtihad Sesuai Santifik-Modern. Teraju, 2003.

Benton, Lauren. 'Colonial Law and Cultural Difference: Jurisdictional Politics and the Formation of the Colonial State', Comparative Studies 
in Society and History, 41 (1999), 563-88.

Bûthî, Muhammad Sa'îd Ramadhân al-, Dhawâbith al-Mashlahah Fî alSyarîah al-Islâmiyyah. Bayrût: Dâr al-Muttahidah, 1992.

Chandler, Stephen S. 'The Role of the Trial Judge in the Anglo-American Legal System', American Bar Association Journal, 50 (1964), 125.

Cruz, Peter De. Comparative Law in a Changing World. Cavendish Pub., 1999.

Fasseur, Cees. 'Colonial Dilemma: Van Vollenhoven and the Struggle between Adat Law and Western Law in Indonesia', in The Revival of Tradition in Indonesian Politics. Routledge, 2007.

. 'Cornerstone and Stumbling Block: Racial Classification and the Late Colonial State in Indonesia, The Late Colonial State in Indonesia: Political and Economic Foundations of the Netherlands Indies, 1942 (1880), 31-56.

Friedman, Lawrence M. 'Sistem Hukum Perspektif Ilmu Sosial', Bandung: Nusa Media, 2009

Fuady, Munir. Teori-Teori dalam Sosiologi Hukum. Ttp.: Kencana, 2015. Galudra, G., and M. Sirait. 'A Discourse on Dutch Colonial Forest Policy and Science in Indonesia at the Beginning of the 20th Century', 2009. <https://doi.org/info:doi/10.1505/ifor.11.4.524>

Ghazali, Abd. Moqsith. Reorientasi Istinbath NU dan Operasionalisasi Ijtihad Jama'i, Dalam Kritik Nalar Fiqih NU (Jakarta: Lakpesdam, 2002)

Ghazzali, Muhammad Sulayman. 'al-Mustasfâ Min Ilm al-Usûl', ttp.: Tnp., 1997.

Glendon, Mary Ann. The Transformation of Family Law: State, Law, and Family in the United States and Western Europe. University of Chicago Press, 1996.

Gunawan, Imam. 'Perspectives of Pancasila: Leadership Education's Values and Ethics', 2nd ICET Theme: "Improving the Quality of Education and Training Through Strengthening Networking”, 2016, 417

Ibrahim, Duski. Metode Penetapan Hukum Islam: Membongkar Konsep 
al-Istiqra' al-Ma'nawi asy-Syatibi. Yogyakarta: Ar-Ruzz Media, 2008.

Ishaque, Shabnam. 'Islamic Principles On Adoption: Examining The Impact of Illegitimacy and Inheritance Related Concerns In Context of A Child'S Right To An Identity', International Journal of Law, Policy and the Family, 22 (2008), 393-420. <https://doi.org/10.1093/ lawfam/ebn009>

Jaspan, M. A. 'In Quest of New Law: The Perplexity of Legal Syncretism in Indonesia*', Comparative Studies in Society and History, 7 (1965), 252-66. <https://doi.org/10.1017/S0010417500003674>

Jawziyyah, Ibn al-Qayyim al-, and Abi Bakr Ayyub. 'I'lam al-Muwaqqiî̀n 'an Rabb al-'Alamîn'. Bayrût: Dâr al-Kutub al-'Ilmiyah, 1991.

Jimly, Asshiddiqie. 'Pembaharuan Hukum Pidana di Indonesia'. Bandung: Angkasa, 1996

Kamali, Mohammad Hashim. "Maqâsid al-Sharîah": The Objectives of Islamic Law', Islamic Studies, 38 (1999), 193-208.

Kansil, C. S. T. Pengantar Ilmu Hukum dan Tata Hukum Indonesia. Jakarta: Balai Pustaka, 1992.

Kato, Tsuyoshi. 'Different Fields, Similar Locusts: Adat Communities and the Village Law of 1979 in Indonesia', Indonesia, 1989, 89-114. $<$ https://doi.org/10.2307/3351077>

Legrand, Pierre. 'European Legal Systems Are Not Converging', International \& Comparative Law Quarterly, 45 (1996), 52-81. <https://doi.org/10.1017/S0020589300058656>

Lev, Daniel S., 'Colonial Law and the Genesis of the Indonesian State', in Law and Society in East Asia. Routledge, 2017.

Lukito, Ratno. 'Law and Politics in Post Independence Indonesia: A Case Study of Religious and Adat Courts', Studia Islamika, 6 (1999).

Majid, Nurcholish. Islam: Doktrin dan Peradaban: Sebuah Telaah Kritis Tentang Masalah Keimanan, Kemanusiaan, dan Kemodernan. Jakarta: Yayasan Wakaf Paramadina, 2000.

Masamah, Ulfa, and Mualimul Huda, 'Multicultural Education and The Nationalistic Reality (Photograph The Role of Teachers In 
Building A Multicultural Awareness In Indonesia)', QIJIS (Qudus International Journal of Islamic Studies), 4 (2016), 68-81. <https:// doi.org/10.21043/qijis.v4i1.1578>

Mattei, Ugo. 'Three Patterns of Law: Taxonomy and Change in the World's Legal Systems', The American Journal of Comparative Law, 45 (1997), 5-44. <https://doi.org/10.2307/840958>

M.D., Moh. Mahfud, and Tirto Suwondo. Hukum dan Pilar-pilar Demokrasi. Yogyakarta: Gama Media, 1999.

Qarafi, Shihab al-Din al-. 'Sharh Tanqîh al-Fusûl Fi Ikhtisâr al-Mahsûl Fi al-Usûl, Ed', Taha'Abd al-Ra’ uf Sa'd. Cairo: Maktabat al-Kulliyyat al-Azhariyya, 1973.

Razi, Fajr al-Din al-. Al-Mahsul Fiilm Usul Al-Figh. Ttp.: Dar al-Kutub al-Ilmiyya, 1988.

Safioedin, Asis. Beberapa Hal Tentang Burgerlijk Wetboek. Jakarta: Alumni, XVI, 1973.

Salam, Izzuddin bin 'Abd al-, 'Qawaid al-Ahkâm Fi Masâlih al-Anam'. Bayrût: Libanon Muassasat al-Rayyan, 1998.

Supomo, Raden. 'The Future of Adat Law in the Reconstruction of Indonesia', Southeast Asia in the Coming World, 1953, 217-35

Syaukani, Imam. Rekonstruksi Epistemologi Hukum Islam Indonesia dan Relevansinya Bagi Pembangunan Hukum Nasional. Jakarta: RajaGrafindo Persada, 2006.

Syatibi, Abu Ishaq al-. 'al-Muwâfaqat Fi Usûl al-Syarîah (Vol. 1)'. Kairo: Dâr Kutub al-'Ilmiyah, 2003

Szczepanski, Kallie. 'Land Policy and Adat Law in Indonesia's Forests', Pacific Rim Law \& Policy Journal, 11 (2002), 231.

Tahir, Masnun. 'Pemikiran T. M. Hasbi Ash-Shiddieqy: Sumber Hukum Islam dan Relevansinya dengan Pemikiran Hukum Islam di Indonesia', Al-Ahwal: Jurnal Hukum Keluarga Islam, 1 (2016), 117-52.

Timmer, Jaap. 'Being Seen like the State: Emulations of Legal Culture in Customary Labor and Land Tenure Arrangements in East Kalimantan, Indonesia', American Ethnologist, 37 (2010), 703-12. <https://doi.org/10.1111/j.1548-1425.2010.01279.x> 
Von Benda-Beckmann, Franz, and Keebet Von Benda-Beckmann. 'Myths and Stereotypes About Adat Law: A Reassessment of Van Vollenhoven in the Light of Current Struggles Over Adat Law in Indonesia, Bijdragen Tot de Taal-, Land-En Volkenkunde, 167 (2011), 167-95 Zaid, Mustafa. 'al-Maslahah Fi al-Tasyri' al-Islâmi Wa Najmuddin al-Tûfi', Bayrût: Dâr al-Fikr, 1954. 